
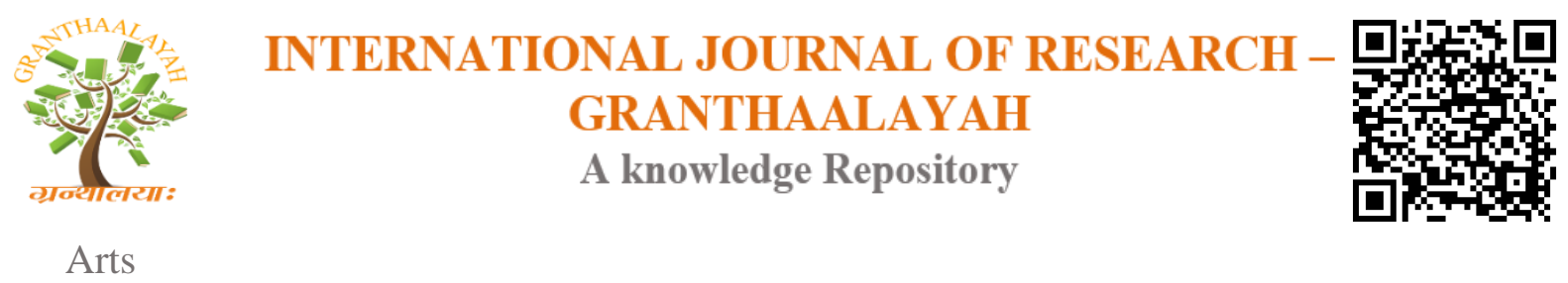

\title{
LINKAGE OF ARTS AND HUMANITIES: AN ENVIRONMENTAL APPRAISAL OF IRAN
}

\author{
Dr. Mohammad Taghi Sheykhi *1 \\ ${ }^{* 1}$ Professor of Sociology, Department of Social Science, Alzahra University, Tehran
}

\begin{abstract}
Graphic signs and symbols could largely affect the changing environment by the youth and within the youth in the present societies with special reference to the developing Iran. Transfer of young cohorts to cities in search of better income and higher quality of life has extensively impacted the urban environment through more emissions, more transportation, more consumption and the like. Increasing understanding of ecological system, promoting efforts to prevent damage to the environment, declaring national policies to the encourage productive and enjoyable harmony between man and environment and improving understanding among the families and the youth in association with the natural and built- environment, all could be supervised and controlled by graphic informatics. Graphics as a theoretical paradigm explores the relationship between human culture and the natural environment. In the present survey, some 419 youth of the both genders were interviewed through designed questionnaires.
\end{abstract}

Keywords: Changing Ecology; Urban Environment; The Youth. Graphics; National Policies.

\begin{abstract}
Aims
Environment graphic design as a comprehensive method of art is in association with many dimensions of life - especially the built-environmental. The main aim of the present study is to identify how the social environment is ever changing, and what part can graphic design paly to contribute to the changing environment. Due to the social change appearing in societies, youth's tastes and desires are ever changing. However, graphic design could bridge between the newly built-environment and the values of the youth. Sociologically speaking, the phenomenon is quite observable in urban environments both in developed and developing societies. Graphic design deters the cultural lag with special reference to the youth.

Cite This Article: Dr. Mohammad Taghi Sheykhi. (2018). "LINKAGE OF ARTS AND HUMANITIES: AN ENVIRONMENTAL APPRAISAL OF IRAN." International Journal of Research - Granthaalayah, 6(9), 17-28. https://doi.org/10.5281/zenodo.1435201.
\end{abstract}

\section{Introduction}

Some of the experiments done by the environmental graphic designers may include planning, wayfinding/consulting, entertainment environment, information and map design as well as 
memorial programs (Heskett,1980). The field developed through origins in signage and branding, and requires practitioners to be familiar with communication and information design. It is also relevant to materials, processes, and fabrication in addition to building codes and project specific standards requirements. Experiential graphic design practitioners are frequently trained in graphic design, industrial design, interior design, architecture and practice in an organization/firm related with the work. However, the whole functions and activities lead to a healthy environment (Kirkham, 1999).

Industrial design is also a part and parcel of the issue. It is a process of design applied to products which are intended to be manufactured in a mass volume (Noblet, 1993). The creative act of determining and defining the form of a product happens in advance of the physical act of making a product, which consists of purely automated replication (Noblet, 1993). The paper come to know of the ideas of the youth saying that a healthy environment is subject to the application of environmental graphic design. On the other hand, craft-based design is a form of design in which the form of the product is determined by the product's creator at the time of being created. The role of industrial designer while taking into account the environment, is to create and execute design solutions for problems of form, function, usability and so on compatible to the environment.

The birth of industrial design is specifically linked to the emergence of industrialization and mechanization that began through the industrial revolution in Great Britain in the mid- $18^{\text {th }}$ century (Heskett, 1980). The emergence of industrial manufacture changed the whole process the objects were made, similarly, urbanization contributed to the changing patterns of consumption followed by growth tasted and diversified markets, and the appearance of a larger middle class; all having impact on environment (Benton,2000). Through the spreading of industrialization, gradually the environment was impacted in different parts of the world - a phenomenon which is escalating every day. However, graphic design trends need to be paralleled with social change and development (Kliever, 2016).

\section{Method of Research}

Research procedure employed in the present paper includes two techniques of investigation. In the former part, the author has reviewed available evidence, literature and theories related to the problem of research- drawing upon others' ideas to clarify the issues which are to be searched. That has mainly been done through approaching library sources. However, the study has used both qualitative and quantitative research methods. While qualitative data has been obtained from various sources and documents, in the latter part, the quantitative data have been obtained through completing questionnaires. In this stage, 500 young families were randomly selected from different neighbourhoods of Tehran with varying socio-cultural and economic backgrounds. As the samples were young educated cohorts, they were quite familiar with public opinion polling, and thus, they well cooperated. It is to be noted that our samples belonging to young generation, are quite open, and their comments reliable. To complete the designed questionnaires, some questioners were employed from certain students/assistants who were first trained and briefed about how to approach the young-family samples. Therefore, every single young family within the "study population" was approached by the questioners. In this way, the questionnaires were administered and the required and intended data were collected. 
The researcher has used observation too, where needed to elicit the necessary data. In addition, some informants and experts aware of the research problem have been interviewed as well. The quantitative method has made possible the efficient collection of data on large numbers of families - allowing for comparisons to be made between the answers of respondents.

\section{Theoretical Perspectives and Literature}

Sociological theories can help us tie the materials together. So, we can grasp how environmental concerns reflect the operation of society. There are various perspectives of health- related quality of life as related to individuals (Fitzpatrick, 1996). The first follows on from the subjective wellbeing and life satisfaction approach towards quality of life. This is known as the personal or experimental approach, and it relates to people's judgements about their own health -related quality of life. The second is more impersonal and objective, i.e. "scientific" in nature, and relies on statistical models derived from responses to hypothetical questions by samples of the general public (Morreim,1992). This is known as the consensus or normative approach, and raises the most problematic and controversial issues about the matters of quality of life. The new industrial conditions, quality and timing of work have contributed to shortage of time with for the parents, particularly the father to spend very little time with their child(ren), and the consequences of which negatively affect emotional atmosphere of the family, quality of life and family networks.

However, young families' quality of life is defined as the optimum levels of physical and social functioning, including relationships and perceptions of health, life satisfaction and well-being. Moving from the individual to the community level of health-related quality of life, one enters the territory of the discipline of social epidemiology that studies the collective characteristics that determine the health status of communities and societies (Berkman et al.,2000). In other words, social epidemiologists ask the question, why are some communities and societies healthier than others? In dong so, their aim is to uncover the foundations of good health, social health and healthy environment.

So far as the environment is concerned, it is ever changing. Both physical and biological environments have been undergoing changes. The ever changing "Dynamic Environment" surroundings under which families exist and develop, highly influence their quality of life. One typical feature of family dynamics is that, the quality of life of which is constantly prone to environmental change. That is to say, environment means conditions of life, and the one which influences family structure.

Principally speaking, need creates value (Rafipoor, 1999:27). The point of value interpretation is to establish the values towards which an activity is directed; it is not to judge such activities either good or bad. However, social order depends on the existence of general, shared values which are regarded as legitimate and binding, and acts as a standard by means of which the ends of action are selected. For example, for sustaining health, having access to hygienic facilities is a new value in modern time. Therefore, a chain of new values constantly contribute to the promotion of quality of life. 
Similarly, as a holistic construct, quality of life has a reciprocal relationship with development, and in that, all the efforts of development are multidimensionally connoted towards improvement in quality of life. By achieving that, one feels healthy, happy and satisfied.

The theoretical impact assessment could be asserted and enunciated as such:

1) Increasing understanding of ecological system.

2) Promoting efforts to prevent damage to the environment.

3) Declaring national policy to encourage productive and enjoyable harmony between man and environment.

4) Improving understanding among the families in general and young families (whose number is high) in particular, of the natural and built environment.

Theoretical frame of environmental health declares that the environmental factors could be nutritional, chemical, biological, or psychological. Non-nutrious diets, infectious agents, toxic chemicals, physical factors, and psychological stress, all play serious roles in affecting the quality of life of the families, particularly the younger ones which are larger in numbers.

Number of children also count for quality of life. In a survey conducted by the statistical center of Iran in Islamshahr (towards south of Tehran), the desired number of children for sample households has been reported 2.2 on average by the respondents (SCI, 2004:40). Such idea stems from aspiring higher quality of life through smaller families within the young families.

Structural-functional paradigm offers important insights about the environment. One of the relevant approaches is the one that highlights the importance of values and beliefs to the operation of a social system. Thus, in simple terms, the state of environment depends largely on how we think about the natural world, for values guide human action (Macionis 1997,402). Structuralfunctionalist theory points up the interconnectedness of various dimensions of social life. Similarly, closely allied with structural-functional theory is cultural ecology, a theoretical paradigm that explores the relationship between human culture and the natural environment. This paradigm broadens our analysis by exploring, not just how a society's culture affects the environment, but also how the environment shapes human culture.

Social-conflict theory highlights the very issues that structural functionalism tends to overlook; power and inequality. Extending this idea, social-conflict analysis also reminds us that the global disparity of wealth and power has critical environmental consequences. Conflict theorists who embrace a Marxist view of society argue that capitalism itself poses a threat to the environment.

Various perspectives regarding urbanism have also been examined in order to prove the assumption. The evolution of cities depends on the development of agriculture; meaning by which only when optimistically agriculture produces a surplus, people with draw their labour from food production and gather in cities to spend time in other pursuits. Therefore, more efficient agricultural techniques provide impetus to urban development.

When increasing numbers of people come together and form cities, problems are created; particularly those pertaining to meeting people's needs, urban environmental issues, physical 
needs including food, shelter and safety. Therefore, some people find the sense of community in the city, but many do not (Henslin, 1983: 434).

Based on Louis Wirth's theory of diversities in cities (1897-1952) of Chicago School of urban sociology, urban ecology has become meeting ground for debate across the physical and social sciences. They result in growing and complex issues in urban environments. Based on Louis Wirth's view, large population, dense settlements and social diversity in cities interact to form an impersonal, superficial and transistory way of life. However, diversity of thinking and way of life in cities can create the basis for more wide-ranging critical debates.

\section{Healthy Environment Concept}

Healthy city could be reached only when there is a balanced coordination between different sectors. It also highly depends on good governance and environmental management. According to (McGranahan et al., 2001), environmental problems of poor people in poor cities tend to be more localized, more immediate and more threatening to well-being than the environmental problems of affluent people in affluent cities.

Cities in stagnant and declining economies that experienced rapid population growth in the last two decades of the twentieth century, are currently exemplifying the poor environments with reference to health and controversial conditions.

To further stress on population impacts, Eastern China would be a good example. Although there is rapid growth in income in that region, where many cities are industrializing, yet environmental conditions often lag seriously (Bai,2003). Sometimes environmental threats are both visible and linked to government corruption and dysfunction which eventually create civil unrest.

Today, many industrializing cities are growing through export-oriented manufacturing; producing goods sold to consumers, including those in rich cities. The environmental pressures that result from this manufacturing, and the labour force that produces it, may be thought of as having been transferred in part from rich nations' industrial base. Such a process has resulted in the emergence and proliferation of slum conditions in many cities in developing countries including Iran.

A city is a combined entity of physical and social mechanism for acquiring and delivering health and ecosystem services to a dense human population. The physical part of this mechanism is often called infrastructure; whereas the social part is called government. However, human life/health in cities is structured by infrastructure such as water and food supply, sewage treatment, energy supply, transportation and communications, technologies to improve air quality, and structures to house people. Financing and maintaining all these need human and material capital. Therefore, conditions such as adequate per capita income, adequate and safe water and food, shelter and transportation must be available in order to reach urban and environmental health (Mitlin et al., 2004). 


\section{Environmental Health}

Environmental health comprises those aspects of human health and diseases that are determined by factors in the environment. It also refers to the theory and practice of assessing and controlling factors in the environment that can potentially affect the health of family members. Environmental health includes both direct pathological effects of chemicals, radiation and some biological agents, and the broad physical, psychological, social and aesthetic environment which includes housing, family, urban development, land use and transport.

The overall goal of the environmental health is to prevent and reduce disease and ill health caused by our environment. Poor environmental quality contributes to 25 to $33 \%$ of global ill health (WHO,2007). Environmental health comprises those aspects of human health including quality of life. It includes those factors in the environment that can potentially affect adversely the health of present and future generations.

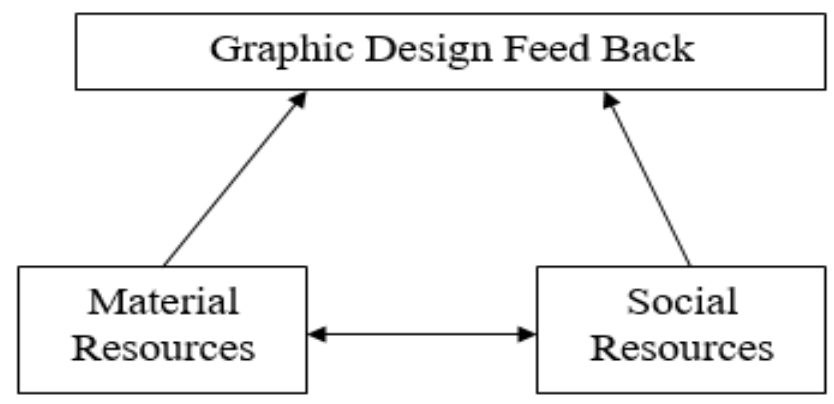

Diagram 1: Simplified Conceptual Graphic Design Model

\section{Social Quality of Life}

Social quality of life is intended to be comprehensive, and to encompass both objective and subjective interpretations. The central themes in that, are resources and social relations. Social quality of life has three conditional factors such as, Socio-economic security, social inclusion, and social cohesion.

Social inclusion refers to participation and processes of being included in collective identities, and the realities that determine self-realization. Social inclusion is connected with the principles of equality, and its structural causes. It refers to the possibility of participation in economic, political, social and cultural systems and institutions, especially by the young families (Beck, 2001:346). Social cohesion is the nature of social relations based on shared identities, values and norms. Young families based on social cohesion and social integration will have the chance of accessing higher quality of life. The domains of social cohesion within the family network would include, trust, other integrative norms and values, social networks and identity in which graphic design plays a major role.

\section{Young Families in Tehran}

The Iranian government has been emphatic on investment in young families in Tehran as a key strategic objective of the country's economic growth and social development policy in the past three decades more due to expanding of urban areas under the pressure of immigration. The emphasis on Tehran has been more than other cities because of its strategic role in country's 
planning and development. Giving priority to Tehran stimulates related private-sector investments - contributing to poverty eradication by providing the foundation for social development. It is ever receiving increasing attention in various dimensions. Such circumstances have contributed to the uncontrolable enlargement of cities which has led to environmental hazards.

The various problems faced by the families in the mega-city of Tehran, inter alia, includes environmental pollution, traffic congestion, housing, employment, youth problems, street children, marginal dwelling etc. In other words, some dimensions of sustainable development such as demographic dynamics, human health and human settlement, poverty and class differences are among the concerns and challenges which families in Iran face, and that contributes to pressures on Tehran from various social, economic, health and environmental dimensions. Therefore, meeting the basic human needs of growing young families, is dependent on a healthy environment. These human dimensions need to be given attention enough in the context of environmental health.

However, demographic factors, combined with poverty and lack of access to resources in some areas, and excessive consumption and wasteful production patterns in others, cause problems of environmental degradation and resource depletion, and thus inhibit sustainable development in the country with a focus on Tehran.

In Iran, particularly in Tehran, pressure on environment has resulted from rapid population growth, distribution and migration of people especially with reference to ecologically vulnerable ecosystem. Urbanization and policies that do not recognize the need for rural development, have also contributed to environmental problems. However, the following five components must be put into practice in order to have access to urban and environmental health; leading to improved quality of life within young families,

While Tehran needs to provide employment and services on a scale sufficient to take care of current residents and new arrivals, employment for all has become critical. Under such conditions many turn to illegal jobs which practically lead to environmental problems and hazards.

Based on a general rule, larger urban areas are more productive; they allow for greater specialization in labour use, better matching of skills and jobs and a wider array of consumption choices for workers (World Development Report,2003). Such a scenario is well apparent in Tehran - where more people than the carrying capacity of the city have amassed.

Based on researches conducted, not all the exploding urban areas can meet the increasing needs of their youth, many of them are severely strained. Therefore, only very few such as Japan can provide for cities with upward of 30 million people (Macionis, 1997:581). Hence for many poor nations such as Mexico, Brazil, Iran etc. supercities are unable to respond to increasing people's needs.

\section{Environmental Education vs. Environmental Health}

Environmental education can play a determining part in lowering environmental problems and consequently enhancing environmental health. Various challenges and needs could be responded through environmental education, and hence healthy city quality could be sustained. 
It will broadly help in resolving environmental issues. For this reason, the municipality of Tehran has established a few "Centers for Citizenship Training" in order to brief the people among others on environmental issues. That is, a type of behavior which depends on the perceptions of the people as well as the society.

Education for social and environmental change requires an understanding of the way people define their own situation (Lucas, 1980, Huckle,1993). Therefore, it acts as a prerequisite of planning and creating healthy city environment.

Sociologically speaking, poverty reduction schemes generally play a vital role in creating healthy cities. In addition, increasing literacy rates highly improve quality of life in cities, and that is quite noticeable in Tehran as compared with other towns and cities in Iran.

While Iran's rate of urbanization is nearly 1 percent per year at national level (SCI, 2002:6), that of Tehran is highly much more, and that adds to the vulnerability of the city so far as the environmental health is concerned. Similarly, while well-planned housing can create conditions conductive to health and hygiene leading to healthy growth of human civilization, it is not happening so in Tehran. As compared with many neighbouring countries, it is good, but it has yet a long way to go to reach the accepted standards.

\section{Reflection of Data}

In the present section, the author tends to appraise the data collected through questionnaires which were then edited and tabulated. The current statistical description would reflect a clear picture of the youth studied in Tehran. A clear reflection of the characteristics, and attributes of the youth could be empirically possible through the data assessment.

The assessment and comparison of the data collected would reflect the youth quality of life in various socio-economic contexts. Since conclusions finally drawn are based on the steps already taken; i.e. editing, analysis, tabulation etc., it is essential to mention that all the steps have carefully been taken in the hope that no flaw has been left in the whole process at any stage.

Out of the total 419 youth studied, $142(33.9 \%)$ cases were males, and 277 (66.1\%) were female youth.

Table 1: Classification of the relevant youths by sex and age in Tehran City

\begin{tabular}{|l|l|l|l|l|l|l|}
\hline \multirow{2}{*}{ Age groups } & \multicolumn{2}{|l|}{ Total } & \multicolumn{2}{l|}{ Males } & \multicolumn{2}{l|}{ Females } \\
\cline { 2 - 7 } & No & \% & No & \% & No & \% \\
\hline Age & 419 & 100 & 142 & 33.9 & 277 & 66.1 \\
\hline $\mathbf{1 8 - 1 9}$ & 102 & 24.3 & 25 & 6.0 & 77 & 18.4 \\
\hline $\mathbf{2 0 - 2 1}$ & 128 & 30.5 & 24 & 5.7 & 104 & 24.8 \\
\hline $\mathbf{2 2 - 2 3}$ & 51 & 12.2 & 16 & 3.8 & 35 & 8.4 \\
\hline $\mathbf{2 4 - 2 5}$ & 54 & 12.9 & 26 & 6.2 & 28 & 6.7 \\
\hline $\mathbf{2 6 - 2 7}$ & 36 & 8.6 & 23 & 5.5 & 13 & 3.1 \\
\hline $\mathbf{2 8 - 2 9}$ & 48 & 11.5 & 28 & 6.7 & 20 & 4.8 \\
\hline
\end{tabular}


Table 2: Abridged Tables

2.1: Classification of Youth 18-29 by sex and age, and how far the word "environment" denotes graphic design as the built environment in Tehran City

\begin{tabular}{|l|l|l|l|l|l|l|l|l|l|l|}
\hline \multirow{2}{*}{ Sex \& Age } & \multicolumn{2}{|l|}{ Total } & \multicolumn{2}{l|}{ Agreed } & \multicolumn{3}{l|}{ Agreed to Some extent } & \multicolumn{2}{|l|}{ Disagreed } & \multicolumn{2}{l|}{ Not sure } \\
\cline { 2 - 13 } & No & $\%$ & No & $\%$ & No & $\%$ & No & $\%$ & No & $\%$ \\
\hline Males \& Females & 419 & 100 & 178 & 44.6 & 136 & 32.5 & 33 & 7.9 & 63 & 15 \\
\hline Males & 142 & 38.1 & 61 & 14.6 & 42 & 10 & 15 & 3.6 & 24 & 5.7 \\
\hline Females & 277 & 61.9 & 126 & 30.1 & 94 & 22.4 & 18 & 4.3 & 39 & 9.3 \\
\hline
\end{tabular}

2.2: Classification of Youth 18-29 by sex and age, and how far the graphic designers help the environmental health in Tehran City

\begin{tabular}{|l|l|l|l|l|l|l|l|l|l|l|}
\hline \multirow{2}{*}{ Sex \& Age } & \multicolumn{2}{l|}{ Total } & \multicolumn{2}{l|}{ Agreed } & \multicolumn{2}{l|}{ Agreed to Some extent } & \multicolumn{2}{l|}{ Disagreed } & \multicolumn{2}{l|}{ Not sure } \\
\cline { 2 - 13 } & No & $\%$ & No & $\%$ & No & $\%$ & No & $\%$ & No & $\%$ \\
\hline Males \& Females & 419 & 100 & 180 & 43 & 146 & 34.8 & 37 & 8.8 & 56 & 13.4 \\
\hline Males & 142 & 33.9 & 60 & 14.3 & 77 & 11.2 & 19 & 4.5 & 16 & 3.8 \\
\hline Females & 277 & 66.1 & 120 & 28.6 & 99 & 23.6 & 18 & 4.3 & 40 & 9.5 \\
\hline
\end{tabular}

2.3: Classification of Youth 18-29 by sex and age, and the role of an environmental graphic designer in execution of solutions to solve the bio-environmental problems in Tehran City

\begin{tabular}{|l|l|l|l|l|l|l|l|l|l|l|}
\hline \multirow{2}{*}{ Sex \& Age } & \multicolumn{2}{|l|}{ Total } & \multicolumn{2}{l|}{ Agreed } & \multicolumn{3}{l|}{ Agreed to Some extent } & \multicolumn{2}{|l|}{ Disagreed } & \multicolumn{2}{l|}{ Not sure } \\
\cline { 2 - 13 } & No & $\%$ & No & $\%$ & No & $\%$ & No & No & $\%$ \\
\hline Males \& Females & 419 & 100 & 16 & 27.7 & 149 & 35.6 & 79 & 18.9 & 75 & 17.9 \\
\hline Males & 142 & 33.9 & 35 & 8.4 & 49 & 11.7 & 31 & 7.4 & 27 & 6.4 \\
\hline Females & 277 & 66.1 & 81 & 19.3 & 100 & 23.9 & 48 & 11.5 & 48 & 11.5 \\
\hline
\end{tabular}

2.4: Classification of Youth 18-29 by sex and age, and how far the graphic design can contribute to the upcoming environmental space to be built later in Tehran City

\begin{tabular}{|l|l|l|l|l|l|l|l|l|l|l|}
\hline \multirow{2}{*}{ Sex \& Age } & \multicolumn{2}{|l|}{ Total } & \multicolumn{2}{l|}{ Agreed } & \multicolumn{2}{l|}{ Agreed to Some extent } & \multicolumn{2}{l|}{ Disagreed } & \multicolumn{2}{l|}{ Not sure } \\
\cline { 2 - 13 } & No & $\%$ & No & $\%$ & No & $\%$ & No & No & $\%$ \\
\hline Males \& Females & 419 & 100 & 215 & 50.6 & 107 & 25.5 & 48 & 11.5 & 52 & 12.4 \\
\hline Males & 142 & 33.9 & 67 & 16 & 34 & 8.1 & 19 & 4.5 & 22 & 5.3 \\
\hline Females & 277 & 66.1 & 145 & 34.6 & 73 & 17.4 & 29 & 6.9 & 30 & 7.2 \\
\hline
\end{tabular}

2.5: Classification of Youth 18-29 by sex and age, and how far the development of graphic designers as a basis of environment is needed after the extensions of urbanization in Tehran City

\begin{tabular}{|l|l|l|l|l|l|l|l|l|l|l|}
\hline \multirow{2}{*}{ Sex \& Age } & \multicolumn{2}{|l|}{ Total } & \multicolumn{2}{l|}{ Agreed } & \multicolumn{2}{l|}{ Agreed To Some extent } & \multicolumn{2}{l|}{ Disagreed } & \multicolumn{2}{l|}{ Not sure } \\
\cline { 2 - 14 } & No & $\%$ & No & $\%$ & No & $\%$ & No & No & $\%$ \\
\hline Males \& Females & 419 & 100 & 178 & 42.5 & 112 & 26.7 & 59 & 14.1 & 70 & 16.7 \\
\hline Males & 142 & 33.9 & 60 & 14.3 & 46 & 11.0 & 17 & 4.1 & 19 & 4.5 \\
\hline Females & 277 & 66.1 & 118 & 28.2 & 66 & 15.8 & 42 & 10.0 & 51 & 12.2 \\
\hline
\end{tabular}


2.6: Classification of Youth 18-29 by sex and age, and how environment graphic design studies contribute to the relationship between citizens and environment in Tehran City

\begin{tabular}{|l|l|l|l|l|l|l|l|l|l|l|}
\hline \multirow{2}{*}{ Sex \& Age } & \multicolumn{2}{|l|}{ Total } & \multicolumn{2}{l|}{ Agreed } & \multicolumn{2}{|c|}{ Agreed to Some extent } & \multicolumn{2}{|c|}{ Disagreed } & \multicolumn{2}{l|}{ Not sure } \\
\cline { 2 - 12 } & No & $\%$ & No & $\%$ & No & $\%$ & No & $\%$ & No & $\%$ \\
\hline Males \& Females & 419 & 100 & 202 & 48.2 & 105 & 25.1 & 41 & 9.8 & 71 & 16.9 \\
\hline Males & 142 & 33.9 & 71 & 16.9 & 34 & 8.1 & 12 & 2.9 & 25 & 6.0 \\
\hline Females & 277 & 66.1 & 131 & 31.3 & 71 & 16.9 & 29 & 6.9 & 46 & 11.0 \\
\hline
\end{tabular}

2.7: Classification of Youth 18-29 by sex and age, and how far the outcomes of environmental graphic design add to the environmental values and improve it in Tehran City

\begin{tabular}{|l|l|l|l|l|l|l|l|l|l|l|}
\hline \multirow{2}{*}{ Sex \& Age } & \multicolumn{2}{|l|}{ Total } & \multicolumn{2}{l|}{ Agreed } & \multicolumn{2}{l|}{ Agreed to Some extent } & \multicolumn{2}{|c|}{ Disagreed } & \multicolumn{2}{l|}{ Not sure } \\
\cline { 2 - 12 } & No & $\%$ & No & $\%$ & No & $\%$ & No & $\%$ & No & $\%$ \\
\hline Males \& Females & 419 & 100 & 200 & 47.7 & 116 & 27.7 & 47 & 11.2 & 56 & 13.4 \\
\hline Males & 142 & 33.9 & 68 & 16.2 & 35 & 8.4 & 21 & 5.0 & 18 & 4.3 \\
\hline Females & 277 & 66.1 & 132 & 31.5 & 81 & 19.3 & 26 & 6.2 & 38 & 9.1 \\
\hline
\end{tabular}

2.8: Classification of Youth 18-29 by sex and age, and how far environmental graphic design boots the citizens' feelings towards environment in Tehran City

\begin{tabular}{|l|l|l|l|l|l|l|l|l|l|l|}
\hline \multirow{2}{*}{ Sex \& Age } & \multicolumn{2}{|l|}{ Total } & \multicolumn{2}{|l|}{ Agreed } & \multicolumn{2}{|l|}{ Agreed to Some extent } & \multicolumn{2}{|l|}{ Disagreed } & \multicolumn{2}{l|}{ Not sure } \\
\cline { 2 - 12 } & No & $\%$ & No & $\%$ & No & $\%$ & No & $\%$ & No & $\%$ \\
\hline Males \& Females & 419 & 100 & 208 & 49.6 & 117 & 27.9 & 44 & 10.5 & 50 & 11.9 \\
\hline Males & 142 & 33.9 & 66 & 15.8 & 45 & 10.7 & 17 & 4.1 & 14 & 3.3 \\
\hline Females & 277 & 66.1 & 142 & 33.9 & 72 & 17.2 & 27 & 6.4 & 36 & 8.6 \\
\hline
\end{tabular}

2.9: Classification of Youth 18-29 by sex and age, and how far environmental graphic design involving creation of from and combination of colors that have aesthetic values in Tehran City

\begin{tabular}{|l|l|l|l|l|l|l|l|l|l|l|}
\hline \multirow{2}{*}{ Sex \& Age } & \multicolumn{2}{|l|}{ Total } & \multicolumn{2}{l|}{ Agreed } & \multicolumn{3}{|l|}{ Agreed To Some extent } & \multicolumn{2}{l|}{ Disagreed } & \multicolumn{2}{l|}{ Not sure } \\
\cline { 2 - 11 } & No & $\%$ & No & $\%$ & No & $\%$ & No & $\%$ & No & $\%$ \\
\hline Males \& Females & 419 & 100 & 154 & 36.8 & 152 & 36.3 & 47 & 11.2 & 66 & 15.8 \\
\hline Males & 142 & 33.9 & 38 & 9.1 & 61 & 14.6 & 21 & 5.0 & 22 & 5.3 \\
\hline Females & 277 & 66.1 & 116 & 27.7 & 91 & 21.7 & 26 & 6.2 & 44 & 10.5 \\
\hline
\end{tabular}

2.10: Classification of Youth 18-29 by sex and age, and how far the art of environmental graphic design is responsible from planning landscape, environmental protection, parks etc. in Tehran City

\begin{tabular}{|l|l|l|l|l|l|l|l|l|l|l|}
\hline \multirow{2}{*}{ Sex \& Age } & \multicolumn{2}{|l|}{ Total } & \multicolumn{2}{l|}{ Agreed } & \multicolumn{2}{|l|}{ Agreed to Some extent } & \multicolumn{2}{|c|}{ Disagreed } & \multicolumn{2}{l|}{ Not sure } \\
\cline { 2 - 12 } & No & $\%$ & No & $\%$ & No & $\%$ & No & $\%$ & No & $\%$ \\
\hline Males \& Females & 419 & 100 & 118 & 28.2 & 155 & 37.0 & 54 & 12.9 & 92 & 22.0 \\
\hline Males & 142 & 33.9 & 39 & 9.3 & 59 & 14.1 & 17 & 4.1 & 27 & 6.4 \\
\hline Females & 277 & 66.1 & 79 & 18.9 & 96 & 22.9 & 37 & 8.8 & 65 & 15.5 \\
\hline
\end{tabular}


2.11: Classification of Youth 18-29 by sex and age, and how environmental graphic contributes to recreational facilities, children's playground, parks etc. in Tehran City

\begin{tabular}{|l|l|l|l|l|l|l|l|l|l|l|}
\hline \multirow{2}{*}{ Sex \& Age } & \multicolumn{2}{|l|}{ Total } & \multicolumn{2}{l|}{ Agreed } & \multicolumn{2}{|c|}{ Agreed to Some extent } & \multicolumn{2}{|c|}{ Disagreed } & \multicolumn{2}{l|}{ Not sure } \\
\cline { 2 - 12 } & No & $\%$ & No & $\%$ & No & $\%$ & No & $\%$ & No & $\%$ \\
\hline Males \& Females & 419 & 100 & 137 & 32.7 & 175 & 41.8 & 44 & 10.5 & 63 & 15.0 \\
\hline Males & 142 & 33.9 & 34 & 8.1 & 65 & 15.5 & 13 & 3.1 & 30 & 7.2 \\
\hline Females & 277 & 66.1 & 103 & 24.6 & 110 & 26.3 & 31 & 7.4 & 33 & 7.8 \\
\hline
\end{tabular}

2.12: Classification of Youth 18-29 by sex and age, and how environmental graphics contribute to city planning, city squares, sea-side spaces, planning of pavements and parking planning in

Tehran City

\begin{tabular}{|l|l|l|l|l|l|l|l|l|l|l|}
\hline \multirow{2}{*}{ Sex \& Age } & \multicolumn{2}{|l|}{ Total } & \multicolumn{2}{|l|}{ Agreed } & \multicolumn{2}{|l|}{ Agreed to Some extent } & \multicolumn{2}{|l|}{ Disagreed } & \multicolumn{2}{l|}{ Not sure } \\
\cline { 2 - 12 } & No & $\%$ & No & $\%$ & No & $\%$ & No & $\%$ & No & $\%$ \\
\hline Males \& Females & 419 & 100 & 157 & 37.5 & 150 & 35.3 & 41 & 9.8 & 71 & 16.9 \\
\hline Males & 142 & 33.9 & 46 & 11.0 & 49 & 11.7 & 16 & 3.8 & 31 & 7.4 \\
\hline Females & 277 & 66.1 & 111 & 26.5 & 101 & 24.1 & 25 & 6.0 & 40 & 9.5 \\
\hline
\end{tabular}

2.13: Classification of Youth $18-29$ by sex and age, and how far the environmental graphics helps in creation of water resources, dams, power stations and industrial projects in Tehran City

\begin{tabular}{|l|l|l|l|l|l|l|l|l|l|l|}
\hline \multirow{2}{*}{ Sex \& Age } & \multicolumn{2}{|l|}{ Total } & \multicolumn{2}{|c|}{ Agreed } & \multicolumn{2}{|c|}{ Agreed to Some extent } & \multicolumn{2}{l|}{ Disagreed } & \multicolumn{2}{l|}{ Not sure } \\
\cline { 2 - 12 } & No & $\%$ & No & $\%$ & No & $\%$ & No & $\%$ & No & $\%$ \\
\hline Males \& Females & 419 & 100 & 88 & 21.0 & 127 & 30.3 & 84 & 20.0 & 120 & 28.6 \\
\hline Males & 142 & 33.9 & 25 & 6.0 & 42 & 10.0 & 31 & 7.4 & 44 & 10.5 \\
\hline Females & 277 & 66.1 & 63 & 15.0 & 85 & 20.3 & 53 & 12.6 & 76 & 18.1 \\
\hline
\end{tabular}

2.14: Classification of Youth 18-29 by sex and age, and how far the environmental graphics contributes in building a combination of a traditional and modern image of the City in Tehran

\begin{tabular}{|l|l|l|l|l|l|l|l|l|l|l|}
\hline \multirow{2}{*}{ Sex \& Age } & \multicolumn{2}{|l|}{ Total } & \multicolumn{2}{|l|}{ Agreed } & \multicolumn{2}{|c|}{ Agreed to Some extent } & \multicolumn{2}{|l|}{ Disagreed } & \multicolumn{2}{l|}{ Not sure } \\
\cline { 2 - 12 } & No & $\%$ & No & $\%$ & No & $\%$ & No & $\%$ & No & $\%$ \\
\hline Males \& Females & 419 & 100 & 189 & 45.1 & 96 & 22.9 & 59 & 14.1 & 75 & 17.9 \\
\hline Males & 142 & 33.9 & 67 & 16.0 & 30 & 7.2 & 23 & 5.5 & 22 & 5.3 \\
\hline Females & 277 & 66.1 & 122 & 29.1 & 66 & 15.8 & 36 & 8.6 & 53 & 12.6 \\
\hline
\end{tabular}

\section{Conclusion}

The changing world is widely appearing as a result of various factors. One of the dimensions of which is environmental graphic design. Young age cohorts of 18-29 are widely subject to change as a result of changing environments. The youth are mutually affected by the environment, and affect the environment as well. Youth's tastes and desires which are ever changing, is often due to the new industrial and graphic designs which emerge because of speedy industrialization and the relevant dimensions. Industrial design, or the process of design applied to products that are to be manufactured through various techniques of mass production impact the youth more than other age groups. However, all industrial products are the result of a design process. But, the nature of this process may take many and different forms. The designer can be an individual or a team. The result could lead to creativity and decision-making; it can affect the prevailing social, economic or 
aesthetic attributes. Similarly, the role of an industrial designer is to bring about and execute design solutions for the problems in the current changing world.

Environmental graphic design is the design of outdoor public areas, landmarks and structures to achieve environmental, social and behavioral outcomes. It involves the systematic investigation of existing social and ecological conditions and processes. It can also shape and mould the attitudes of the youth with special reference to the urban areas. The built-environment, or the human-made surroundings that provide settings for human activities including buildings, parks, green space for neighborhoods and cities often need the creativity of graphic designers. However, the changing world of the current time highly relies on newly built-environments.

\section{References}

[1] Bai, Xuemi, 2003 The Process and Mechanism of Urban and Environmental Change, An Evolutionary View, International Journal of Environment and Pollution, Vol.19, PP.528-541.

[2] Beck, W., van der Maeson, L. and Walker, A., 2001, Theorizing Social Quality, P.346, The Hague, Kluwer Law International.

[3] Berkman, L. and Glass, T. 2000, Social Integration and Social Networks, Social Networks, Social Supports and Health in Berkman and Kawachi, I., Social Epidemiology, New York, Oxford University Press.

[4] Fitzpatrick, R., 1996, Alternative Approaches to the Assessment of Health-related Quality of Life, Oxford, Oxford University Press.

[5] Henslin, J.M., 1983, Social Problems, New York, McGraw-Hill, Inc.

[6] Kupper, A., and Kupper, J., 1996, Social Science Encyclopedia, P.287, New York, Routledge.

[7] Huckle, J., 1993, Education for Sustainability, Assessing Pathways to the Future, Australian Journal of Environmental Education, 7, PP. 49 and 69.

[8] Lucus, M.A., 1980, The Role of Science Education in Education for Environmental Education, 12(3) PP. 3 and 23.

[9] Macionis, J.,1997, Sociology, P.581, London, Prentice-Hall.

[10] Macionis, J.J., 1998, Society, P.347, London, Prentice-Hall.

[11] Mitlin, D. et al., 2004, Empowering Squatter Citizen, Local Government, Civil Society and Urban Poverty Reduction, London, Earth Scan.

[12] McGranaham, G., et al., 2001, The Citizens at Risk, From Urban Sanitation to Sustainable Cities, London, Earth Scan.

[13] Morreim, H., 1992, The Impossibility and Necessity of Quality of Life Research, Bioethics, 6, 21832.

[14] Parsons, Talcott, 1955, the American Family, Its Relations to Personality and to the Social Structure, New York, Free Press.

[15] Rafipoor, F., 1999, The Anatomy of Society, P.271, Tehran, Enteshar Publication Co.

[16] Results of Sample Survey of Fertility Health in Selected Cities of Tehran Province, P.40, Tehran, Statistical Centre of Iran Publications.

[17] State Statistical Year Book of Iran,2002, P.6, Statistical Centre of Iran.

[18] Turner, B.S., et al., 2002, Penguin Dictionary of Sociology, P.373, London, Penguin Group.

[19] Uberoi, N.K.,2003, Environmental Management, New Delhi, Excel Books.

[20] Wirth, Louis, "Urbanism as a Way of Life", American Journal of Sociology, July 1983, 1-24.

[21] World Health Organization United Nations, 2007.

*Corresponding author.

E-mail address: mtshykhi@ alzahra.ac.ir/mtshykhi@yahoo.com 